\section{High microbial loads found in minimally-processed sliced mushrooms from Italian market}

\author{
Haiyang Jiang, ${ }^{1,2}$ Dino Miraglia, ${ }^{1}$ \\ David Ranucci, ${ }^{1}$ Domizia Donnini, ${ }^{3}$ \\ Rossana Roila, ${ }^{1}$ Raffaella Branciari, ${ }^{1}$ \\ Cheng $\mathbf{L i}^{2}$
}

${ }^{1}$ Department of Veterinary Medicine, University of Perugia, Italy; ${ }^{2}$ College of Food Science, Sichuan Agricultural University, Ya'an, Sichuan, China; ${ }^{3}$ Department of Agricultural, Food and Environmental Sciences, University of Perugia, Italy

\begin{abstract}
There is an increased consumer interest in minimally processed vegetables that has led to the development of products, such as pre-cut sliced mushrooms. Few data are available on the hygienic condition and the presence of foodborne pathogens in such products. Therefore, the current study aimed to evaluate the safety and hygienic characteristics of both ready-to-eat and ready-to-cook, pre-cut sliced mushrooms obtained from a local Italian market. For the evaluation of the hygienic condition, the aerobic mesophilic bacteria, aerobic psychrotrophic bacteria and Escherichia coli enumerations were performed. Salmonella spp., Listeria monocytogenes and Campylobacter spp. were considered in the assessment of the foodborne pathogens. High microbial loads were detected, including counts higher than $5 \log \mathrm{CFU} / \mathrm{g}$ for $E$. coli and $6 \log \mathrm{CFU} / \mathrm{g}$ for the other bacteria counts considered, but no pathogens were found. Ready-to-eat and ready-to-cook products differed only for aerobic mesophilic counts (7.87 and 8.26 log $\mathrm{CFU} / \mathrm{g}$, respectively, $\mathrm{P}=0.003)$. Strategies to enhance the hygienic level of the mushrooms, particularly the ready-to-eat products, are needed.
\end{abstract}

\section{Introduction}

The shift to a fast lifestyle in several countries has led to an increasing demand for minimally processed foods that are ready-to-eat or easy to prepare. Nowadays, people tend to spend less time preparing meals than in the past, but there is an increasing interest in healthy and high nutritional quality foods (Jeddi et al., 2014). Among these foods, there is an increasing demand for fresh-cut vegetables and fruits (Oliveira et al., 2015), with several products available in the market, such as minimally processed mushrooms (Venturini et al., 2011) that are sold both for ready-to-eat or ready-to-cook purposes. Ready-to-eat food, as reported by EC Regulation 2073/2005, means food intended by the producer or the manufacturer for direct human consumption without the need for cooking or other processing effective to eliminate or reduce to an acceptable level micro-organisms of concern; ready-to-cook are pre-packaged food prepared for convenience consumption after cooking containing raw vegetables (Chung et al., 2010) and the need to be cook condition is highlighted directly in the products label.

Fresh-cut vegetables that undergo minimal processing have physicochemical characteristics that allow the growth of several microorganisms, such as juices rich in nutrients, high humidity and $\mathrm{a}_{\mathrm{w}}$ values (AyalaZavala et al., 2008; Mahajan et al., 2008; Ragaert et al., 2007). To date, literature about the hygiene and safety of fresh-cut products has focused mainly on salad vegetables, spinach, carrots and lettuce (Abadias et al., 2008; Brandão et al., 2014; Cardamone et al., 2015; Sagoo et al., 2003a). Although the hygienic and safety condition of fresh, whole (not cut), cultivated mushrooms are reported (McMahon and Wilson, 2001; Venturini et al., 2011; Kim et al., 2016) no data, to our knowledge, are yet available on pre-cut sliced mushrooms sold for ready-to-eat and ready-to-cook purposes. Furthermore, the European Commission (EC) legislation has established process hygienic criteria and safety food criteria for Salmonella in pre-cut (ready-to-eat) vegetables (EC Regulation 2073/2005 amended by EC Regulation 1441/2007), but it is not clear if vegetables include mushrooms. According to the legislation, the safety criteria for Listeria monocytogenes is applicable to all ready-to-eat foods.

The current study aimed to evaluate the hygienic level of ready-to-eat and ready-tocook pre-cut sliced mushrooms available in the Italian market and the presence of foodborne pathogens in these products.

\section{Materials and methods}

A total of 50 pre-cut sliced mushrooms (Agaricus bisporus, Imbach, 1946), packaged in polystyrene trays covered with stretch-film and stored at $4^{\circ} \mathrm{C}$, were randomly sampled from eight point-of-sales in Perugia (central Italy) but produced in various Italian regions. No information were available regarding the gas mix and the permeability of the film used in the packs.
Correspondence: David Ranucci, Department of Veterinary Medicine, University of Perugia, Via San Costanzo 4, 06126, Perugia, Italy. Tel.: +39.075.5857931 - Fax: +39.075.5857928. E-mail: david.ranucci@unipg.it

Key words: Agaricus bisporus, pre-cut sliced mushrooms, Escherichia coli, Salmonella, Listeria.

Contributions: the authors contributed equally

Conflict of interests: the authors declare no potential conflict of interests.

Funding: none.

Received for publication: 28 November 2017 Accepted for publication: 31 December 2017.

This work is licensed under a Creative Commons Attribution-NonCommercial 4.0 International License (CC BY-NC 4.0).

(C) Copyright H. Jiang et al., 2018

Licensee PAGEPress, Italy

Italian Journal of Food Safety 2018; 7:7000

doi:10.4081/ijfs.2018.7000

\section{Microbiological analysis}

The samples, 25 ready-to-eat and 25 ready-to-cook, pre-cut sliced mushrooms, were promptly sent to the laboratory. Each sample was aseptically collected and divided into four aliquots of $25 \mathrm{~g}$ of mushrooms: one for the aerobic mesophilic count (AMC) (ISO 4833:2004), aerobic psychrotrophic count (APC) (ISO 17410:2001) and Escherichia coli count (AFNOR AES10/06-10/08); one for Salmonella spp. isolation (ISO 6579:2002); one for L. monocytogenes isolation and enumeration (EN/ISO 11290-1: 2017a and 11290-2: 2017b) and one for Campylobacter spp. isolation (ISO 10272-1:2006). All the analyses were conducted in duplicate, for each product.

For the microbial loads, the results were reported as colony-forming units per gram $(\mathrm{CFU} / \mathrm{g})$ and transformed into $\log 10 \mathrm{val}-$ ues.

\section{Physicochemical determinations}

Additionally, 10 randomly collected samples were analysed for water activity $\left(\mathrm{a}_{\mathrm{w}}\right)$, by using an Aqua Lab water activity meter (Series 3 TB, Decagon Devices Inc., Pullman, WA, USA), and for $\mathrm{pH}$, by inserting a $\mathrm{pH}$ probe (Crison Instruments, Barcelona, Spain) into the mushrooms.

\section{Statistical determination}

Descriptive statistics were performed on all data obtained. Comparisons between the average data for ready-to-eat and readyto-cook mushrooms were evaluated by one- 
way analysis of variance (ANOVA), using StatView software (SAS, Cary, NC, USA), followed by Tukey's test with a significance level set at $\mathrm{P}<0.05$.

\section{Results}

The average $\mathrm{pH}$ value of the mushrooms was 6.88 [standard deviation $(\mathrm{SD})=$ $0.14]$, ranging from $\mathrm{pH}$ 6.62-7.01 and 6.737.12 in ready-to-eat and ready-to-cook products, respectively. The $\mathrm{a}_{\mathrm{w}}$ values were always above 0.99 , with an average value of $0.997(\mathrm{SD}=0.001)$.

Table 1 presents the microbial counts obtained for all the samples tested. The average loads were always over $7 \mathrm{log}$ $\mathrm{CFU} / \mathrm{g}$ for all microbial counts considered. E. coli counts in all the samples were over 5 $\log \mathrm{CFU} / \mathrm{g}, \mathrm{APC}$ were over $6 \log \mathrm{CFU} / \mathrm{g}$ and $\mathrm{AMC}$ over $7 \log \mathrm{CFU} / \mathrm{g}$.

A significant difference was found in the AMC between ready-to-eat mushrooms (7.87 $\pm 0.37 \log \mathrm{CFU} / \mathrm{g}$ ) and ready-to-cook mushrooms $(8.26 \pm 0.49 \log \mathrm{CFU} / \mathrm{g})$ $(\mathrm{P}=0.003)$. However, no differences were registered between these two groups of products, regarding the APC and E. coli loads (Figure 1).

The products were negative for either Salmonella spp., or Campylobacter spp. or L. monocytogenes. Listeria spp. growth was observed on three samples, but the species was identified as Listeria innocua by biochemical methods (API Listeria, Oxoid, Basingstoke, UK) (data not reported).

\section{Discussion}

The results highlight high levels of microbial loads for all the bacteria counts considered. Similar data are not available for pre-cut sliced mushrooms at the retail level, but a comparison is attempted with other mushrooms used for decontamination trials or with other minimally processed vegetables, including mushrooms, obtained from the market. In washed and cut mushrooms, used as the control in decontamination trials by pulsed light, Oms-Oliu et al.
(2010) found lower values than those observed in the present study. The AMC and APC were above $6 \log \mathrm{CFU} / \mathrm{g}$ but the mushrooms were cut and immediately processed, which may have influenced the microbial growth rate. The AMC levels reported by Venturini et al. (2011) was similar to those found in the present study (average value of $7.7 \mathrm{log} \mathrm{CFU} / \mathrm{g}$ ), even if uncut mushrooms were considered. Moreover, the surface of mushrooms is not favourable for microbial growth, due to the presence of a cuticle, and only after cutting there is an increase in the microbial loads, because of the nutrients released available for the microorganisms (Ragaert et al., 2007). For minimally processed vegetables, there is a broad range of aerobic mesophilic and aerobic psychrotrophic loads in freshcut vegetables reported in the literature with values higher (De Oliveira et al., 2011, APC values of $9.4 \log$ CFU/g in arangula, $9.3 \mathrm{log}$ $\mathrm{CFU} / \mathrm{g}$ in spring onion/parsley mixture and $9.0 \log \mathrm{CFU} / \mathrm{g}$ in spinach), similar (Soriano et al., 2000, AMC ranging from 3.01-7.81 $\log \mathrm{CFU} / \mathrm{g}$ in 144 ready-to-eat lettuce samples; Valentin-Bon et al., 2008, average AMC from 100 bagged lettuce and spinach mixes was 7 log CFU/g; Santos et al., 2012, APC ranged from 4.65-8.48 log CFU/g in fresh-cut salads) or lower (Maistro et al., 2012, AMC from 4.00-6.89 log CFU/g in six kinds of minimally processed vegetables with non-modified atmosphere packages; Cerna-Cortes et al., 2015, AMC from 3.0 to $6.6 \log \mathrm{CFU} / \mathrm{g}$ in ready-to-eat salads; Cardamone et al., 2015, AMC between 5 and $7 \mathrm{log}$ CFU/g in minimally processed leafy vegetables) than those found in precut sliced mushrooms.

The high microbiological counts registered in both ready-to-eat and ready-to-cook pre-cut sliced mushrooms represent poor hygienic quality, which means that hygienic measures need to be improved during processing. The AMC detected, despite showing a significant difference between readyto-eat and ready-to-cook mushrooms $(\mathrm{P}<0.05)$, highlights that mushrooms could be contaminated before or during the harvest process, or during processing/packaging procedures. During mushroom growing, contamination by soil, irrigation water, manure or sewage sludge use and animals are possible (Ragaert et al., 2007). Then, during the harvesting and post harvesting process, microorganisms can growth, due to physical damage to the plant tissues (Leong et al., 1991; Zagory et al., 1999). Following, all post-harvest mushroom han-

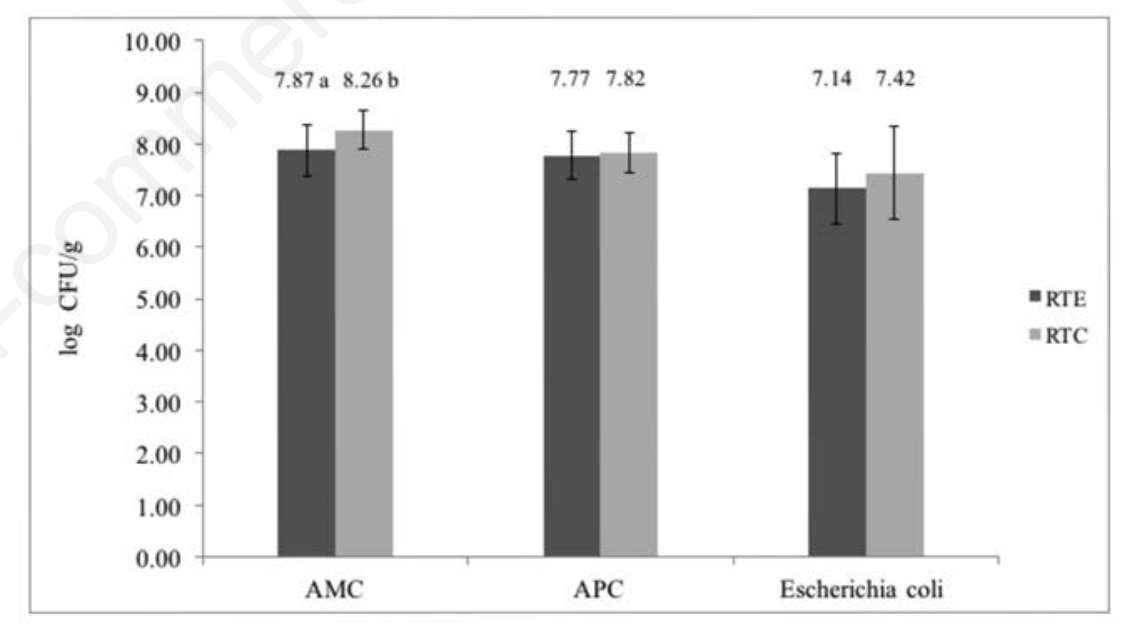

Figure 1. Microbial loads in the two groups of fresh-cut mushrooms.

Table 1. Total microbial loads in fresh-cut mushrooms.

\begin{tabular}{|c|c|c|c|c|c|c|c|c|c|}
\hline \multirow[t]{2}{*}{ Parameter } & \multirow{2}{*}{$\begin{array}{l}\text { Samples } \\
\text { (n) }\end{array}$} & \multicolumn{4}{|c|}{ Number of positive samples (\%) } & \multirow[b]{2}{*}{$\begin{array}{c}>10^{8} \\
\mathrm{CFU} / \mathrm{g}\end{array}$} & \multirow{2}{*}{$\begin{array}{c}\text { Mean } \\
\log \text { CFU/g }\end{array}$} & \multirow{2}{*}{$\begin{array}{c}\text { Standard } \\
\text { deviation log } \\
\text { CFU/g }\end{array}$} & \multirow{2}{*}{$\begin{array}{c}\text { Range log } \\
\text { CFU/g }\end{array}$} \\
\hline & & $\begin{array}{l}<10^{5} \\
\mathrm{CFU} / \mathrm{g}\end{array}$ & $\begin{array}{l}10^{5-6} \\
\mathrm{CFU} / \mathrm{g}\end{array}$ & $\begin{array}{c}10^{6-7} \\
\mathrm{CFU} / \mathrm{g}\end{array}$ & $\begin{array}{l}10^{7-8} \\
\mathrm{CFU} / \mathrm{g}\end{array}$ & & & & \\
\hline Aerobic mesophilic count & 50 & 0 & 0 & 0 & $23(46)$ & $27(54)$ & 8.07 & 0.47 & $7.20-8.86$ \\
\hline Aerobic psychrotrophic count & 50 & 0 & 0 & $1(2)$ & $35(70)$ & $14(28)$ & 7.80 & 0.43 & $6.48-8.60$ \\
\hline Escherichia coli & 50 & 0 & $3(6)$ & $19(38)$ & $19(38)$ & $9(18)$ & 7.21 & 0.81 & $5.48-9.08$ \\
\hline
\end{tabular}


dling stages, including the processes of washing and cutting, could potentially cause hygienic defects. During minimally processing procedures, microbial growth is possible because mushroom slicing creates a large exposed surface area and the lack of a protective barrier (Brennan et al., 1998). Additionally, packaging and storage also allow bacteria to grow (Brennan et al., 2000), due to respiration of fresh mushrooms, with large amounts of water vapour in the package (Singh et al., 2010).

For E. coli, Venturini et al. (2011) found both Enterobacteriaceae (3.0 log CFU/g) and total coliforms $(0.3 \log \mathrm{CFU} / \mathrm{g})$ with $E$. coli levels below the values found in this study. Most studies documented low E. coli counts in ready-to-eat vegetables. Campos et al (2013), find $4 \%$ of 50 bagged readyto-eat salads (split or mixed leaves, carrot, corn) with $E$. coli levels $\geq 10^{2} \mathrm{CFU} / \mathrm{g}$. Maistro et al. (2012) also reported low $E$. coli contamination results, with 10 out of 172 minimally processed green vegetables collected from supermarkets in Campinas (Brazil) testing positive, including two of the 17 whole arugula leaves (3.5 and $3.1 \mathrm{log}$ $\mathrm{CFU} / \mathrm{g}$ of E. coli, respectively). Sagoo et al. (2001) analysed 3200 ready-to-eat organic vegetables grown nearby or in contact with soil (including mushrooms), collected from various outlets in the United Kingdom. $E$. coli was detected in $1.5 \%(48 / 3200)$ of the samples and was present at $10^{2} \mathrm{CFU} / \mathrm{g}$ or more in $0.3 \%$ (11) samples. Compared to these investigations, both the loads and prevalence of $E$. coli in our study was higher. Regarding food hygiene criteria for precut vegetables, the Regulation states that $2 / 5$ samples are allowed to detect E. coli, with the limits from 2-3 log CFU/g during the manufacturing process. However, in the mushrooms sampled at market level, the $E$. coli loads detected (more than $5 \log \mathrm{CFU} / \mathrm{g}$ ) were much higher than referred by the Regulation. These situation, considering the storage temperature used for the mushrooms $\left(4^{\circ} \mathrm{C}\right)$, could be due to high level of $E$. coli in the products immediately after packaging.

No Salmonella was detected in pre-cut sliced mushrooms in accordance to Venturini et al. (2011), that could not isolate Salmonella spp. from 402 mushroom samples, representing 22 species of wild and cultivated mushrooms sold in retail markets and supermarkets in Zaragoza (Spain). Salmonella spp. was not detected also in fresh-cut vegetables (Jeddi et al., 2014; Santos et al., 2012; Seow et al., 2012), while a few studies found low percentages of this pathogen (Sant'Ana et al., 2011,
4/512 packages of minimally processed vegetables were found positive for Salmonella spp.; Gómez-Govea et al., 2012, Salmonella Typhi E1 was detected at $0.66 \%$ total frequency and at $<3$ most probable number/g in six fresh produce vegetables).

Regarding L. monocytogenes previous studies found positive samples in mushrooms obtained from retail market. Venturini et al. (2011) found 6.5\% (26/402) and Abadias et al., (2008) found $0.6 \%$ (1/156) positive samples of mushroom collected from several retail establishments in Spain. On the contrary, Leong et al. (2015) found no L. monocytogenes in pre-packaged, whole, fresh, refrigerated mushrooms (A. bisporus) acquired from a supplier in Ireland. In other minimally processed vegetables, low levels of contamination by Listeria microorganism have been highlighted (Giusti et al., 2010; Johannessen et al., 2002). De Oliveira et al. (2011) detected L. monocytogenes in $1.2 \%(2 / 162)$ and $L$. innocua in $2.4 \%(4 / 162)$ samples of minimally processed leafy vegetables commercialised in Brazil. Our study confirmed no L. monocytogenes in 50 pre-cut sliced mushroom samples, but L. innocua was detected in three ready-to-eat samples $(6 \%)$. The results is in agreement with Guerra et al. (2001) that found L. innocua in $4 \%$ $(1 / 23)$ ready-to-eat vegetable samples but no L. monocytogenes. Nonetheless, according to the EU regulation 2073/2005 pre-cut sliced ready-to-eat mushroom species can support the growth of L. monocytogenes as $\mathrm{pH}$ and $\mathrm{a}_{\mathrm{w}}$ are favourable for this pathogen. Moreover, a challenge test showed that $A$. bisporus did not support the growth of $L$. monocytogenes (Leong et al., 2015).

No Campylobacter spp. was found in our research, in agreement with McMahon et al. (2001) and Sagoo et al. (2003a, 2003b).

Although we compared our results with the European Union regulation for the hygienic criteria, that refers to the loads during manufacturing process instead of the selling period, the high microbial load detected need a correct analyses of the level before the products are available in the market and the rate of growth during storage/distribution. Furthermore, good agricultural practices, good manufacturing practice and hazard analysis and critical control points throughout mushroom processing are crucial, and decontamination strategies, like ultraviolet light (Brennan et al., 2000), acidic electrolysed water (Ding et al., 2011) and bacteriocins (Randazzo et al., 2009), could be used to reduce microor- ganisms in fresh-cut mushrooms and minimize risk.

\section{Conclusions}

This study provides a general overview of the microbiological quality of pre-cut sliced mushrooms in Italy. The poor level of hygiene is not associated with the presence of pathogens even if the high level of $E$. coli detected warrants further investigation and the need to define the presence of enterohemorrhagic E. coli. Moreover, a general recommendation to consumers could be to wash pre-cut vegetables and mushrooms before consumption.

\section{References}

Abadias M, Usall J, Anguera M, Solsona C, Viñas I. 2008. Microbiological quality of fresh minimally-processed fruit and vegetable, and sprouts from retail estrablishment. Int $\mathrm{J}$ Food Microbiol 123:121-9.

AFNOR 2015. Enumeration of E. coli + Enterobacteriaceae, AFNOR AES10/06-10/08, Paris, France.

Ayala-Zavala JF, Del-Toro-Sánchez L, Alvarez-Parilla E, González-Aguilar GA, 2008. High relative humidity inpackage of fresh-cut fruits and vegetables: Advantage or disadvantage considering microbiological problems and antimicrobial delivering systems? J Food Sci 73:41-7.

Brandão MLL, Almeida DO, Bispo FCP, Bricio SML, Marin VA, Miagostovich MP, 2014. Assessment of microbiological contamination of fresh, minimally processed, and ready-to-eat lettuces (Lactuca sativa), Rio de Janeiro State, Brazil. J Food Sci 79:961-6.

Brennan M, Le Port G, Gormley R, 2000. Post-harvest treatment with citric acid or hydrogen peroxide to extend the shelf life of fresh sliced mushrooms. Lebensm Wiss Technol 33:285-9.

Brennan MH and Gormley TR, 1998. Extending the Shelf Life of Fresh Sliced Mushrooms. The National Food Centre, Dunsinea, Castleknock, Dublin 15, Ireland.

Campos J, Mourão J, Pestana N, Peixe L, Novais C, Antunes P, 2013. Microbiological quality of ready-to-eat salads: an underestimated vehicle of bacteria and clinically relevant antibiotic resistance genes. Int $\mathrm{J}$ Food 
Microbiol 166:464-70

Cardamone C, Aleo A, Mammina C, Oliveri G, Di Noto AM, 2015. Assessment of the microbiological quality of fresh produce on sale in Sicily, Italy: preliminary results. J Biol Res Thessalon 22:3.

Cerna-Cortes JF, Leon-Montes N, CortesCueto AL, Salas-Rangel LP, HelgueraRepetto AC, Lopez-Hernandez D, Rivera-Gutierrez S, Fernandez-Rendon E, Gonzalez-y-Merchand JA 2015. Microbiological quality of ready-to-eat vegetables collected in Mexico City: occurrence of aerobic-mesophilic bacteria, fecal coliforms, and potentially pathogenic nontuberculous mycobacteria. BioMed Res Int 2015:1-9.

Chung MS, Kim CM, Ha S 2010. Detection and enumeration of microorganisms in ready-to-eat foods, ready-to-cook foods and fresh-cut produce in Korea. J Food Safety 30:480-9.

De Oliveira MA, de Souza VM, Bergamini AMM, De Martinis ECP, 2011. Microbiological quality of ready-to-eat minimally processed vegetables consumed in Brazil. Food Control 22:14003.

Ding T, Rahman SME, Oh DH, 2011. Inhibitory effects of low concentration electrolyzed water and other sanitizers against foodborne pathogens on oyster mushroom. Food Control 22:318-22.

Giusti M, Aurigemma C, Marinelli L, Tufi D, De Medici D, Di Pasquale S, De Vito C, Boccia A. 2010. The evaluation of the microbial safety of fresh ready-toeat vegetables produced by different technologies in Italy. J Appl Microbiol 109:996-1006.

Gómez-Govea M, Solís-Soto L, Heredia N, García S, Moreno G, Tovar O, Isunza G, 2012. Analysis of microbial contamination levels of fruits and vegetables at retail in Monterrey, Mexico. J Food Agric Environ 10:152-6.

Guerra MM, McLauchlin J, Bernardo FA, 2001. Listeria in ready-to-eat and unprocessed foods produced in Portugal. Food Microbiol 18:423-9.

Imbach EJ, 1946. Pilzflora des Kantons Luzern und der angrenzenden Innerschweiz. Mitt, naturf. Ges. Luzern 15:5-85.

ISO, 2001. Microbiology of food and animal feeding stuffs - Horizontal method for the enumeration of psychrotrophic microorganisms. ISO Norm 17410:2001. International Organization for Standardization, Geneva, Switzerland.

ISO, 2002. Microbiology of food and animal feeding stuffs - Horizontal method for the detection of Salmonella spp. ISO Norm 6579:2002. International Organization for Standardization, Geneva, Switzerland.

ISO, 2004. Microbiology of food and animal feeding stuffs. Horizontal method for the enumeration of microorganisms. Colony count technique at 30 degrees C. ISO Norm 4833:2004. International Organization for Standardization, Geneva, Switzerland.

ISO, 2006. Microbiology of food and animal feeding stuffs - Horizontal method for detection and enumeration of Campylobacter spp. - Part 1: Detection method. ISO Norm 102721:2006. International Organization for Standardization, Geneva, Switzerland.

ISO, 2017a. Microbiology of the food chain - Horizontal method for the detection and enumeration of Listeria monocytogenes and of Listeria spp. - Part 1: Detection method. ISO Norm 112901:2017. International Organization for Standardization, Geneva, Switzerland.

ISO, 2017b. Microbiology of the food chain - Horizontal method for the detection and enumeration of Listeria monocytogenes and of Listeria spp. - Part 2: Enumeration method. ISO Norm 11290-2:2017. International Organization for Standardization, Geneva, Switzerland

Jeddi MZ, Yunesian Masud, Gorji ME, Noori N, Pourmand MR, Khaniki GRJ, 2014. Microbial evaluation of fresh, minimally-processed vegetables and bagged sprouts from chain supermarkets. J Health Population Nutr 32:3919.

Johannessen GS, Loncarevic S, Kruse H, 2002. Bacteriological analysis of fresh produce in Norway. Int $\mathrm{J}$ Food Microbiol 77:199-204.

King AD, Magnuson JA, Török T, Goodman N, 1991. Microbial flora and storage quality of partially processed lettuce. J Food Sci 56:459-61.

Leong D, Alvarez-Ordóñez A, Jordan K, 2015. A note on challenge trials to determine the growth of Listeria monocytogenes on mushrooms (Agaricus bisporus). Irish J Agric Food Res 54:121-5.

Mahajan PV, Oliveira FAR, Macedo I, 2008. Effect of temperature and humidity on the transpiration rate of the whole mushrooms. J Food Eng 84;281-8.

Maistro LC, Miya NTN, Sant'Ana AS., Pereira JL, 2012. Microbiological quality and safety of minimally processed vegetables marketed in Campinas, SPBrazil, as assessed by traditional and alternative methods. Food Control 28:258-64.
McMahon MAS, Wilson IG, 2001. The occurrence of enteric pathogens and Aeromonas species in organic vegetables. Int J Food Microbiol 70:155-62.

Oliveira M, Abadias M, Usall J, Torres R, Teixidó N, Viñas I, 2015. Application of modified atmosphere packaging as a safety approach to fresh-cut fruits and vegetables - A review. Trends Food Sci Tech 46:13-26.

Oms-Oliu G, Aguiló-Aguayo I, MartínBelloso O, Soliva-Fortuny R, 2010. Effects of pulsed light treatments on quality and antioxidant properties of fresh-cut mushrooms (Agaricus bisporus). Postharvest Biol Tec 56:216-22.

Ragaert P, Devlieghere F, Debevere J, 2007. Role of microbiological and physiological spoilage mechanisms during storage of minimally processed vegetables. Postharvest Biol Tec 44:185-94.

Randazzo CL, Pitino L, Scifò GO, Caggia C, 2009. Biopreservation of minimally processed iceberg lettuces using a bacteriocin produced by Lactococcus lactis wild strain. Food Control 20:756-63.

Sagoo SK, Little CL, Mitchell RT, 2001. The microbiological examination of ready-to-eat organic vegetables from retail establishments in the United Kingdom. Lett Appl Microbiol 33:4349.

Sagoo SK, Little CL, Ward L, Gillespie IA, Mitchell RT, 2003a. Microbiological study of ready-to-eat salad vegetables from retail establishments uncovers a national outbreak of salmonellosis. J Food Protect 66:403-9.

Sagoo SK, Little CL, Mitchell RT, 2003b. Microbiological quality of open readyto-eat salad vegetables: effectiveness of food hygiene training of management. J Food Protect 66:1581-6.

Sant'Ana AS, Landgraf M, Destro MT, Franco BDGM. 2011. Prevalence and counts of Salmonella spp. in minimally processed vegetables in São Paulo, Brazil. Food Microbiol 28:1235-7.

Santos MI, Cavaco A, Gouveia J, Novais MR, Nogueira PJ, Pedroso L, Ferreira MASS 2012. Evaluation of minimally processed salads commercialized in Portugal. Food Control 23:275-81.

Seow J, Ágoston R, Phua L, Yuk HG, 2012. Microbiological quality of fresh vegetables and fruits sold in Singapore. Food Control 25:39-44.

Singh P, Langowski HC, Wani AA, Saengerlaub S, 2010. Recent advances in extending the shelf life of fresh Agaricus mushrooms: a review. J Sci Food Agric 90:1393-402.

Soriano JM, Rico H, Moltó JC, Mañes J 2000. Assessment of the microbiologi- 
cal quality and wash treatments of lettuce served in University restaurants. Int J Food Microbiol 58:123-8.

Valentin-Bon I, Jacobson A, Monday SR, Feng PCH, 2008. Microbiological quality of bagged cut spinach and lettuce mixes. Appl Environ Microbiol 74:1240-2.

Venturini ME, Reyes JE, Rivera CS, Oria R, Blanco D, 2011. Microbiological quality and safety of fresh cultivated and wild mushrooms commercialized in
Spain. Food Microbiol 28:1492-8.

Zagory D, 1999. Effects of post-processing handling and packaging on microbial populations. Postharvest Biol Tech 15:313-21. 